\title{
GnRH Stimulation Test in Precocious Puberty: Single Sample is Adequate for Diagnosis and Dose Adjustment
}

\author{
Nurgün Kandemir, Hüseyin Demirbilek, Zeynep Alev Özön, Nazlı Gönç, Ayfer Alikaşifoğlu \\ Hacettepe University Medical School, Division of Pediatric Endocrinology, Ankara, Turkey
}

\begin{abstract}
Objective: Gonadotropin stimulation test is the gold standard to document precocious puberty. However, the test is costly, timeconsuming and uncomfortable. The aim of this study was to simplify the intravenous gonadotropin-releasing hormone ( $\mathrm{GnRH})$ stimulation test in the diagnosis of precocious puberty and in the assessment of pubertal suppression.

Methods: Data pertaining to $584 \mathrm{GnRH}$ stimulation tests (314 tests for diagnosis and 270 for assessment of pubertal suppression) were analyzed.

Results: Forty-minute post-injection samples had the greatest frequency of "peaking luteinizing hormone $(L H)$ " $(p<0.001)$ in the diagnostic tests when the cut-off value was taken as $5 \mathrm{IU} / \mathrm{L}$ for $\mathrm{LH}, 40^{\text {th }}$ minute sample was found to have $98 \%$ sensitivity and $100 \%$ specificity in the diagnosis of precocious puberty, while the sensitivity and specificity of the $20^{\text {th }}$ minute sample was $100 \%$ in the assessment of pubertal suppression.

Conclusion: $\mathrm{LH}$ level at the $40^{\text {th }}$ minute post-injection in the diagnosis of central precocious puberty and at the $20^{\text {th }}$ minute post-injection in the assessment of pubertal suppression is highly sensitive and specific. A single sample at these time points can be used in the diagnosis of early puberty and in the assessment of pubertal suppression.

Key words: Central precocious puberty, follicle stimulating hormone, luteinizing hormone, GnRH analogue, hypotalamo-pituitary-gonadal axis, GnRH stimulation test
\end{abstract}

Conflict of interest: None declared Received: 30.12 .2010

\section{Introduction}

Several aspects of the clinical and laboratory diagnosis of central precocious puberty (CPP) need further evaluation. Gonadotropin-releasing hormone ( $\mathrm{GnRH}$ ) stimulation test is the gold standard to document premature activation of the hypothalamic-pituitary-gonadal axis in cases with clinical signs and symptoms of early puberty $(1,2)$. Repeated blood sampling at different time points (5 to 8 times) is required to measure the levels of follicle-stimulating hormone (FSH) and luteinizing hormone (LH) both before and after administration of $\mathrm{GnRH}(3,4,5)$. The duration of the test is 90 to 120 minutes and 15 to $25 \mathrm{~mL}$ of blood is needed for 10 to 16 measurements. The procedure is costly, timeconsuming and uncomfortable for patients. To avoid these problems, several attempts such as measurement of basal gonadotropin levels or subcutaneous leuprolide acetate test with a single sample have been made $(2,6,7,8,9)$. None of these alternative tests have been standardized sufficiently or proven to be equal or superior to $\mathrm{GnRH}$ test as yet. In cases of precocious puberty, the GnRH test may also need to be repeated during treatment with $\mathrm{GnRH}$ analogue to assess the effectiveness of suppression and to adjust the dose of the analogue $(10,11)$.

In the current study, which aimed to investigate whether the testing procedure for diagnosis/assessment of CPP could be simplified without changing its validity, we evaluated the predictive values of FSH and $\mathrm{LH}$ at each time point during the $\mathrm{GnRH}$ test.

\section{Address for Correspondence}

Hüseyin Demirbilek, Hacettepe University Medical School, Division of Pediatric Endocrinology, Sihhiye, Ankara, Turkey Gsm: +90 3123051124 Fax: 3123121809 E-mail:dr_huseyin@hotmail.com

Presented as a poster at $8^{\text {th }}$ Joint Meeting Global Care Pediatrics Endocrinology (LWPES/ESPE)

(c) Journal of Clinical Research in Pediatric Endocrinology, Published by Galenos Publishing. 


\section{Methods}

\section{Diagnostic Group}

This group comprised 263 girls presenting with early pubertal signs. The age of onset as well as the tempo of puberty were extracted from patient records. Physical examination included body weight, height, and estimation of breast and pubic hair development according to the Tanner classification. Bone age was assessed using the Greulich-Pyle method (12).

Indications for $\mathrm{GnRH}$ stimulation test were:

1. Onset of pubertal signs and growth acceleration before the age of 8 years.

2. Accelerated pubertal progression associated with advanced bone age after the age of 8 years.

\section{Group Under Treatment with GnRH Analogue}

Patients whose diagnosis of CPP was confirmed by basal ort ic $\mathrm{GnRH}$ stimulated peak LH were treated with $\mathrm{GnRH}$ analogue (leuprolide acetate) to suppress puberty. These patients constituted this group. All these patients were initially treated with an intramuscular injection of leuprolide acetate $3.75 \mathrm{mg}$ every 28 days. In order to

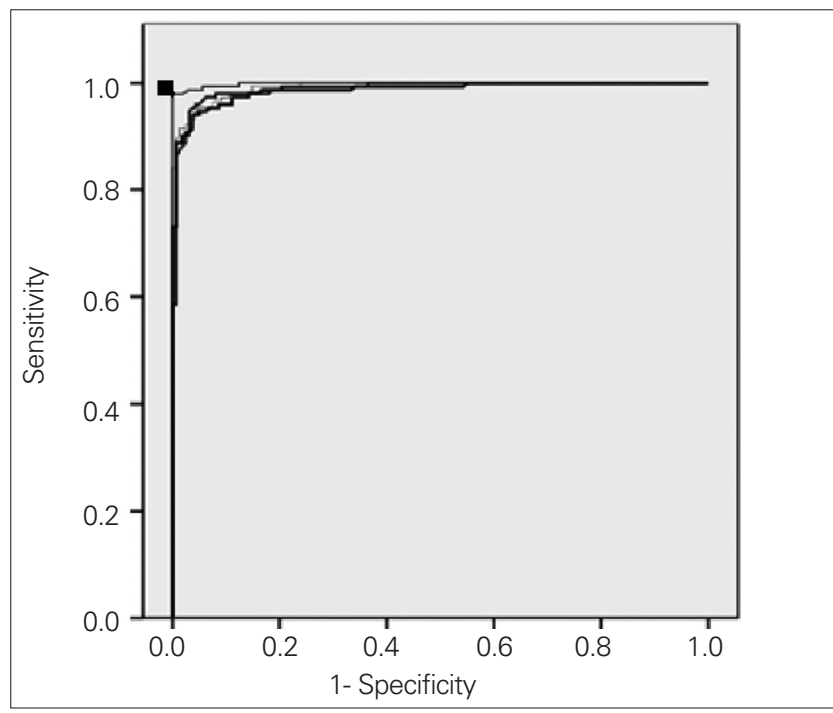

\begin{tabular}{|lccc|}
\hline $\begin{array}{l}\text { Time point of LH } \\
\text { measurement }\end{array}$ & AUC & Sensitivity & Specificity \\
\hline 20th minute & 0.992 & 95.4 & 95.1 \\
$40^{\text {th }}$ minute & 0.999 & 98.0 & 100.0 \\
$60^{\text {th }}$ minute & 0.989 & 96.1 & 95.7 \\
$90^{\text {th }}$ minute & 0.987 & 94.1 & 96.3 \\
\hline
\end{tabular}

Figure 1. The ROC curves of $\mathrm{LH}$ at different time points of the test (20th $40^{\text {th }}, 60^{\text {th }}$ and $90^{\text {th }}$ minutes).

$\mathrm{LH}$ : luteinizing hormone ascertain the adequacy of suppression of puberty in these patients, a repeat $\mathrm{GnRH}$ test was performed in the course of their treatment (re-test). Re-tests were done 3 weeks after the third dose of the $\mathrm{GnRH}$ analogue. In patients with inadequate suppression of puberty, the dose of the $\mathrm{GnRH}$ analogue was doubled (see below).

The $\mathrm{GnRH}$ test was performed at $800-830$ a.m. An intravenous (IV) cannula was inserted and blood samples were collected for basal FSH and LH. Following administration of a standard dose of $100 \mu \mathrm{g} \mathrm{GnRH}$ (Gonadorelin acetate, Ferring ${ }^{\circledR}$ ), blood samples for FSH and LH were obtained at the $20^{\text {th }}, 40^{\text {th }}, 60^{\text {th }}$ and $90^{\text {th }}$ minutes. FSH and $\mathrm{LH}$ were measured using chemiluminescent microparticle immunoassay (ARCHITECH System, Abbott Laboratory Diagnostics, USA). The minimum detectable concentration was $0.07 \mathrm{IU} / \mathrm{L}$ for both FSH and LH. A cut-off value of stimulated $\mathrm{LH}$ of greater than or equal to $5 \mathrm{IU} / \mathrm{L}$ was considered diagnostic for pubertal response in patients with pubertal signs (13). In the course of $\mathrm{GnRH}$ analogue therapy, a cut-off value of less than $2 \mathrm{IU} / \mathrm{L}$ for $\mathrm{LH}$ in IV GnRH stimulation test was deemed to demonstrate adequate suppression of puberty (10).

\section{Statistical Analysis}

Stastistical analysis was carried out using Statistical Package for the Social Sciences, version 15.0 for Windows (SPSS Inc., Chicago, IL). The data are given as means \pm SD. Frequencies were compared using the $\chi^{2}$-test. The Friedman test was used for repeated measures, Wilcoxon rank test and Mann-Whitney $U$ test were used to compare means. A p value of less than 0.05 was considered to be statistically significant.

The diagnostic values of FSH, LH as well as LH/FSH ratio at different time points during $\mathrm{GnRH}$ test were evaluated using receiver operating characteristic (ROC) analysis.

\section{Results}

\section{Diagnostic Group}

Three hundred and fourteen tests for the diagnosis of CPP were performed in 263 girls with signs of early puberty. The mean values for chronological age, height age and bone age were $7.9 \pm 1.5,8.8 \pm 1.8$ and $9.5 \pm 1.9$ years, respectively. The mean body weight was $32.2 \pm 8.2 \mathrm{~kg}$ Pubertal development was compatible with Tanner stage 2 in $62.5 \%$, and with stage 3 in $37.5 \%$ of patients.

The mean LH level at the 40th minute of the test $(7.9 \pm 9.9 \mathrm{IU} / \mathrm{L})$ was higher than the mean values at all other time points $(p<0.001)$. The peak LH level coincided with the $40^{\text {th }}$ minute sample in $71 \%$ of patients, and this occurrence was significantly more frequent at that compared to the other time points $(p=0.03)$ (Table 1). In 152 out of 314 


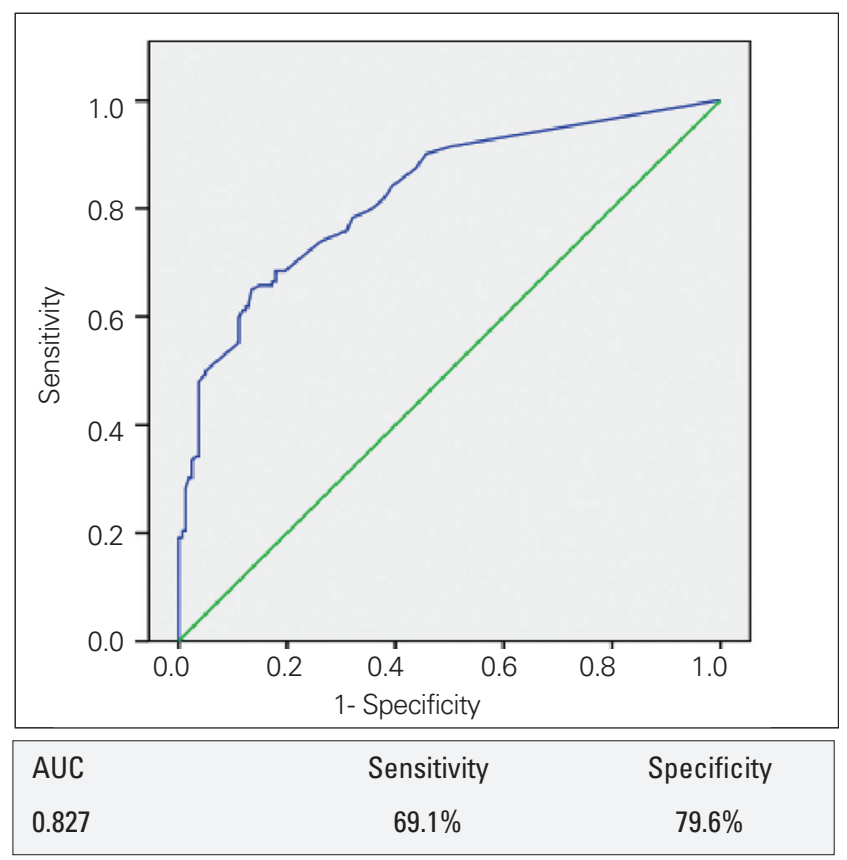

Figure 2. The ROC curve of basal $\mathrm{LH}$ levels in the diagnosis of CPP $\mathrm{LH}$ : luteinizing hormone, CPP: central precocious puberty

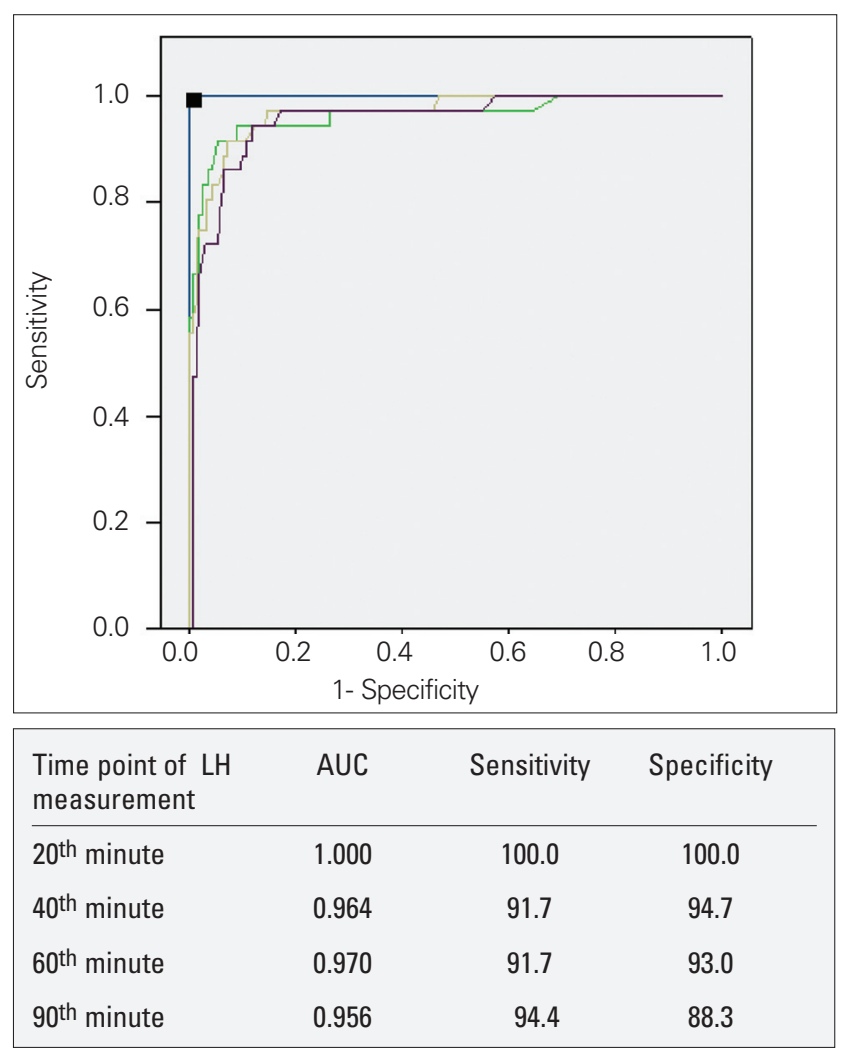

Figure 3. ROC curve of $\mathrm{LH}$ level at different time points of $\mathrm{GnRH}$ tests performed for assessment of pubertal suppression $\mathrm{LH}$ : luteinizing hormone, GnRH: gonadotropin-releasing hormone
(48.4\%) tests, the peak LH was above the cut-off, and the test was diagnostic for CPP. Among these patients, in $149 / 152(98 \%)$ of the tests, the $40^{\text {th }}$ minute sample was diagnostic for CPP with an LH level above $5 \mathrm{IU} / \mathrm{L}$, even if it was not the peak. Also in all prepubertal patients (162 tests), the 40th minute sample LH was below $5 \mathrm{IU} / \mathrm{mL}$, even if $\mathrm{LH}$ did not peak at the $40^{\text {th }}$ minute.

The mean FSH level at the 60th minute of the test was $12.1 \pm 11.3 \mathrm{IU} / \mathrm{L}$, a value higher than those at all other time points $(p<0.001)$. Additionally, at the $60^{\text {th }}$ minute of the tests, the highest frequency of peak FSH (42\%) was obtained (Table 1).

Figure 1 presents the ROC curves of $\mathrm{LH}$ at different time points of the test. The ROC curve for $\mathrm{LH}$ at the $40^{\text {th }}$ minute was the most diagnostic one since it had the greatest area under the curve (AUC). $5 \mathrm{IU} / \mathrm{L}$ was considered as cut-off for $\mathrm{LH}$ in the diagnosis of $\mathrm{CPP}$, and the ROC curves showed that a level of $4.93 \mathrm{IU} / \mathrm{L}$ at the $40^{\text {th }}$ minute was the most sensitive (98\%) and specific (100\%) cut-off for $\mathrm{LH}$ in the diagnosis.

The mean basal LH level in the group with pubertal response to the $\mathrm{GnRH}$ test was higher than that of the prepubertal group $(1.05$ and $0.22 \mathrm{mlU} / \mathrm{L}$, respectively, $p<0.0001)$. However, analysis of the diagnostic value of basal LH using ROC revealed that sensitivity and specificity of basal LH were both low $(69.1 \%$ and $79.6 \%$, respectively) in the diagnosis of CPP (Figure 2). Also, basal LH level in 13 of the 152 (8.5\%) patients with a pubertal response to $\mathrm{GnRH}$ were below the lowest detectable level $(<0.07 \mathrm{IU} / \mathrm{L})$. When we considered basal $\mathrm{LH} \geq 1 \mathrm{IU} / \mathrm{L}$ as the cut-off level for diagnosis of CPP, the positive predictive value of basal LH was $96.4 \%$ and the negative predictive value was $61.8 \%$.

Evaluation of $\mathrm{LH} / \mathrm{FSH}$ ratio demonstrated no statistically significant difference in LH/FSH ratios between prepubertal and pubertal response groups both in the basal state $(p=0.328)$ and in the peaks $(p=0.718)$. Sensitivity and specificity of basal and peak LH levels are shown in Figure 3.

Evaluation of the diagnostic value of $\mathrm{FSH}$ using $\mathrm{ROC}$ analysis revealed that none of the time points, or any levels of FSH were sensitive or specific enough to allow a diagnosis of CPP.

\section{Group Under Treatment with GnRH Analogue}

Two hundred seventy tests were performed to assess pubertal suppression. The results are shown in Table 2. The mean LH level $(1.2 \mathrm{IU} / \mathrm{L} \pm 0.9)$ was higher at the $20^{\text {th }}$ minute of the test in comparison to the other time points $(p<0.001)$. Also, peak LH was noted at the $20^{\text {th }}$ minute in 249 of the 270 patients (92.2\%). Two hundred and thirty-four patients (86.7\%) were found to have a suppressed LH response to $\mathrm{GnRH}$ (peak LH $<2 \mathrm{IU} / \mathrm{L}$ ). The peak LH level in 215 out of 234 patients (91.8\%) with suppressed $\mathrm{GnRH}$ test was at the $20^{\text {th }}$ minute, whereas in 
the remaining 19 patients (8.2\%), the peak LH level was at the 40th minute. In 36 (13.3\%) patients, GnRH-stimulated $\mathrm{LH}$ peak was $\geq 2 \mathrm{IU} / \mathrm{L}$, showing inadequate suppression, and the dose of the $\mathrm{GnRH}$ analogue had to be increased. The 20th minute LH levels were $\geq 2 \mathrm{IU} / \mathrm{L}$ in all patients with inadequate suppression. Also, 20th minute LH levels were $<2 \mathrm{IU} / \mathrm{L}$ in all 234 patients $(100 \%)$ with adequate suppression in response to $\mathrm{GnRH}$ test. In addition, the AUC in ROC analysis was greatest at the 20th minute, with $100 \%$ sensitivity and specificity using a cut-off of 1.98 IU/L for $L H$.

Evaluation of basal $\mathrm{LH}$ values for assessment of pubertal suppression using ROC analysis revealed that basal LH showed pubertal suppression with $83.3 \%$ sensitivity and $67.9 \%$ specificity (AUC was 0.813 and LH cut-off value considered for pubertal suppression was 0.3 $\mathrm{IU} / \mathrm{L})$. According to this cut-off, the negative predictive value and the positive predictive value of basal LH were found to be $96.4 \%$ and $28.5 \%$, respectively.

\section{Discussion}

$\mathrm{GnRH}$ test is the gold standard for the diagnosis of CPP. However, the test is time-consuming, costly and uncomfortable for the patients. In the current study, in an attempt to simplify the $\mathrm{GnRH}$ test, we analyzed the $\mathrm{LH}$ response to the $\mathrm{GnRH}$ test performed to diagnose precocious puberty and also to assess the adequacy of suppression with a $\mathrm{GnRH}$ analogue. Different cut-off values of peak LH are used in the diagnosis of CPP in patients with early pubertal signs, and also in the assessment of pubertal suppression in patients under treatment with a $\mathrm{GnRH}$ analogue. Cut-off values also differ depending on the assay used to measure $\mathrm{LH}$

Table 1. FSH, LH levels and frequency of peak LH and FSH at each time point during the GnRH stimulation test

\begin{tabular}{|c|c|c|c|c|c|}
\hline & Basal & $20^{\text {th }}$ minute & $40^{\text {th }}$ minute & $60^{\text {th }}$ minute & $90^{\text {th }}$ minute \\
\hline LH level (IU/L) (mean \pm SD) & $0.51 \pm 0.8$ & $7.3 \pm 10.0^{\mathrm{a}}$ & $7.9 \pm 9.9^{b}$ & $6.8 \pm 8.2^{\mathrm{a}}$ & $5.1 \pm 6.0$ \\
\hline \multirow[t]{2}{*}{ Frequency of peak LH (\%) } & 0 & 60 & 223 & 29 & 2 \\
\hline & (0) & $(19.1)$ & $(71.0)$ & (9.2) & $(0.6)$ \\
\hline \multirow[t]{2}{*}{ Cross-sectional frequency of $\mathrm{LH} \geq 5 \mathrm{IU} / \mathrm{L}(\%)$} & 0 & 125 & 149 & 127 & 92 \\
\hline & (0) & (82.2) & (98.0) & $(83.6)$ & $(60.5)$ \\
\hline \multirow[t]{2}{*}{ Cumulative frequency of $\mathrm{LH} \geq 5 \mathrm{IU} / \mathrm{L}(\%)$} & 0 & 125 & 151 & 152 & 152 \\
\hline & (0) & (82.2) & (99.3) & $(100)$ & $(100)$ \\
\hline FSH level (IU/mL) (mean \pm SD) & $2.85 \pm 2.6$ & $8.2 \pm 6.2$ & $11.1 \pm 9.8$ & $12.1 \pm 11.3^{\mathrm{C}}$ & $11.9 \pm 11.3$ \\
\hline \multirow[t]{2}{*}{ Frequency of peak FSH (\%) } & 0 & 7 & 55 & 132 & 120 \\
\hline & (0) & (2.2) & (17.5) & (42) & (38.2) \\
\hline
\end{tabular}

Table 2. FSH, LH levels and frequency of peak LH at each time point during the GnRH stimulation test in patients under treatment with GnRH analogue

\begin{tabular}{|c|c|c|c|c|c|}
\hline & Basal & $20^{\text {th }}$ minute & $40^{\text {th }}$ minute & $60^{\text {th }}$ minute & $90^{\text {th }}$ minute \\
\hline LH level (IU/L) (mean \pm SD) & $0.29 \pm 0.2$ & $1.2 \pm 0.9$ & $0.98 \pm 0.7$ & $0.78 \pm 0.6$ & $0.67 \pm 0.9$ \\
\hline Frequency of peak LH (\%) & $\begin{array}{l}0 \\
(0)\end{array}$ & $\begin{array}{c}249 \\
(92.2)\end{array}$ & $\begin{array}{c}21 \\
(7.8)\end{array}$ & $\begin{array}{c}0 \\
(0)\end{array}$ & $\begin{array}{c}0 \\
(0)\end{array}$ \\
\hline Frequency of $\mathrm{LH} \geq 2 \mathrm{IU} / \mathrm{L}(\%)$ & $\begin{array}{c}0 \\
(0)\end{array}$ & $\begin{array}{c}36 \\
(100)\end{array}$ & $\begin{array}{c}18 \\
(50.0)\end{array}$ & $\begin{array}{c}11 \\
(30.5)\end{array}$ & $\begin{array}{c}5 \\
(13.9)\end{array}$ \\
\hline FSH level (IU/L) (mean \pm SD) & $1.15 \pm 0.7$ & $1.89 \pm 1.3$ & $1.93 \pm 1.48$ & $1.83 \pm 1.46$ & $1.66 \pm 1.27$ \\
\hline Frequency of peak FSH (\%) & $\begin{array}{c}0 \\
(0)\end{array}$ & $\begin{array}{c}87 \\
(45.3)\end{array}$ & $\begin{array}{c}80 \\
(41.7)\end{array}$ & $\begin{array}{c}22 \\
(11.5)\end{array}$ & $\begin{array}{c}3 \\
(1.6)\end{array}$ \\
\hline
\end{tabular}


$(5,13,14,15,16)$ In our clinic, LH is measured using ICMA, and $L H \geq 5 \mathrm{IU} / \mathrm{L}$ is considered to be diagnostic for CPP (13), whereas $\mathrm{LH}$ should be below $2 \mathrm{IU} / \mathrm{L}$ in order to consider a patient with CPP under $\mathrm{GnRH}$ analogue treatment as adequately suppressed (10).

Comparison of peak LH levels at different time points during the $\mathrm{GnRH}$ test performed for the diagnosis of CPP showed that the mean $\mathrm{LH}$ value at the $40^{\text {th }}$ minute of the test was greater than those at other time points. Also, a greater number of $\mathrm{LH}$ peaks coincided with the $40^{\text {th }}$ minute samples. These findings suggest that a single sample obtained at the 40th minute of the $\mathrm{GnRH}$ test may be used in the diagnosis of CPP with high sensitivity (98\%) and specificity (100\%).

Previous studies reported $\mathrm{LH}$ to peak between 30 and 60 minutes of the $\mathrm{GnRH}$ test $(5,13,14,17,18,19,20)$, but none of these studies aimed to simplify the standard IV $\mathrm{GnRH}$ test, except the study by Cavallo et al (5). These authors suggested that a single $\mathrm{LH}$ determination at the $30^{\text {th }}$ minute of the test was diagnostic. However, their study included only 55 diagnostic tests in 51 patients. To our best knowledge, the current study comprises the largest homogeneous population in this regard.

Some authors suggest that $\mathrm{LH} / \mathrm{FSH}$ ratio may also be valuable in the diagnosis of $\operatorname{CPP}(3,18,21)$. Jiang et al (18) reported that $\mathrm{LH} / \mathrm{FSH}>0.9$ at the $15^{\text {th }}$ minute of the test might be diagnostic, but with lower sensitivity and specificity (80\% and $90 \%$, respectively). In another study, the peak $\mathrm{LH} / \mathrm{FSH}>1$ was found to have the highest positive predictive value (93.8\%) (22). In the current study, both basal and stimulated LH/FSH ratios had lower sensitivity and specificity in comparison to the peak LH level in the diagnosis of CPP. Similarly, FSH levels, both basal and peak, had poor diagnostic value. Data from other studies also indicate that FSH has a poor diagnostic value in CPP (5).

In the last decade, the use of third-generation assays in the measurement of gonadotropin (FSH and LH) levels enabled clinicians to apply basal LH levels in the diagnosis of $\operatorname{CPP}(6,7)$. Neely et al (6) reported that a basal $\mathrm{LH}>0.1$ IU/L was diagnostic for CPP with $94 \%$ sensitivity and $88 \%$ specificity. They also showed that a cut-off value $>0.3 \mathrm{IU} / \mathrm{L}$ increased the specificity to $100 \%$ even though the sensitivity was reduced. Recently, Houk et al (7) suggested that using a basal $\mathrm{LH}>0.83 \mathrm{IU} / \mathrm{L}$ as the cut-off value yielded high sensitivity (93\%) and specificity (100\%) for the diagnosis of CPP. However, their study included a limited number of patients and the pubertal stage of the patients was not reported. According to our ROC curve analysis, basal LH > $0.3 \mathrm{IU} / \mathrm{L}$ had the highest sensitivitiy $(65.1 \%)$ and specificity (86.4\%). However, these values were lower than those reported in the study by Houk et al (7). When we considered basal $\mathrm{LH}>0.83$ as the cut-off value, the sensitivity was found very low (34.2\%), while the specificity was $96.3 \%$. Furthermore, it was observed that 13 of the
152 patients (8.5\%) diagnosed with CPP in the IV GnRH stimulation test had undetectable basal LH levels. When LH $\geq 1 \mathrm{IU} / \mathrm{L}$ was considered as the cut-off for the diagnosis of $\mathrm{CPP}$, the positive predictive value of basal $\mathrm{LH}$ was found adequate to confirm the diagnosis of CPP without performing an IV GnRH stimulation test. Therefore, we do not suggest using basal $\mathrm{LH}$ as a single diagnostic criteria for CPP, except for $L H \geq 1 \mathrm{IU} / \mathrm{L}$, which displayed a high positive predictive value $(96.4 \%)$.

Analysis of pubertal suppression in 270 patients under treatment with a $\mathrm{GnRH}$ analogue for CPP revealed that $\mathrm{LH}$ level at the $20^{\text {th }}$ minute of the test was $100 \%$ sensitive and specific to determine adequacy of suppression. Previous studies analyzed data regarding both diagnostic and follow-up GnRH tests; however, the specific question about the value of a single LH level to show the adequacy of pubertal suppression was not addressed (13). Cavallo et al (5) analyzed 39 tests in the course of treatment, but, their analysis was inconclusive owing to the small number of cases who were inadequately supressed. Furthermore, because of its low sensitivity and specificity, we do not recommend basal $\mathrm{LH}$ value as a single criterion in the assessment of pubertal supression, with the exception of $\mathrm{LH}<0.3 \mathrm{IU} / \mathrm{L}$, which displayed a high negative predictive value (96.4\%). Therefore, basal LH can be used as a screening test to show pubertal suppression, and in case of $\mathrm{LH} \geq 0.3$, an IV GnRH stimulation test should be performed for dose adjustment. This cut-off value was previously presented as a criterion to differentiate prepubertal from pubertal patients $(6,13)$.

Separate analysis of the $\mathrm{GnRH}$ test in the diagnostic and treatment groups revealed an interesting finding. Gonadotropin levels peaked more rapidly in patients under treatment in comparison to those who were assessed for suppression. FSH levels also peaked more rapidly in the re-test group.

In conclusion, a single sample of $\mathrm{LH}$ obtained at the $40^{\text {th }}$ minute of the $\mathrm{GnRH}$ test may be adequate for the diagnosis of CPP if a cut-off value of $5 \mathrm{IU} / \mathrm{L}$ is applied. Also, our findings indicate that a single measurement of $\mathrm{LH}$ at the 20th minute of the $\mathrm{GnRH}$ test using a cut-off value of 2 $\mathrm{IU} / \mathrm{L}$ is as valid as the standard test to evaluate pubertal suppression in patients under treatment with a $\mathrm{GnRH}$ analogue.

\section{References}

1. Lee PA. Laboratory monitoring of children with precocious puberty. Arch Pediatr Adolesc Med 1994;148:369-376. [Abstract] / [PDF]

2. Preamrudee Poomthavorn, Patcharin Khlairit, Pat Mahachoklertwattana. Subcutaneous GonadotropinReleasing Hormone Agonist (Triptorelin) Test for diagnosing precocious puberty. Horm Res 2009;72:114-119. [Abstract] / [Full Text] / [PDF] 
3. Pescovitz $\mathrm{OH}$, Hench KD, Barners KM, Lorizux DL, Cutler GB. Premature thelarche and central precocious puberty: the relationship between clinical presentation and the gonadotropin response to luteinizing hormone releasing hormone. J Clin Endocrinol Metab 1988;67:474-479. [Abstract] / [PDF]

4. Parker KL, Baens-Bailon RG, Lee PA. Depot leuprolide acetate dosage for sexual precocity. J Clin Endocrinol Metab 1991;73:50-52. [Abstract] / [Full Text]

5. Cavallo A, Richards E, Busey S, Michaels SE. A simplified gonadotrophin-releasing hormone test for precocious puberty. Clin Endocrinol (Oxf) 1995;42:641-646. [Abstract]

6. Neely EK, Wilson DM, Lee PA, Stene M, Hintz RL. Spontaneous serum gonadotropin concentrations in the evaluation of precocious puberty. J Pediatr 1995:127:47-52. [Abstract] / [Full Text] / [PDF]

7. Houk CP, Kunselman AR, Lee PA. Adequacy of a single unstimulated luteinizing hormone level to diagnose central precocious puberty in girls. Pediatrics 2009;123:1059-1063. [Abstract] / [Full Text] / [PDF]

8. Houk CP, Kunselman AR, Lee PA. The diagnostic value of a brief $\mathrm{GnRH}$ analogue stimulation test in girls with central precocious puberty: a single 30-minute post-stimulation $\mathrm{LH}$ sample is adequate. J Pediatr EndocrinAol Metab 2008;21:1113-1118. [Abstract]

9. Ibáñez $L$, Potau $N$, Zampolli $M$, Virdis R, Gussinyé $M$, Carrascosa A, Saenger P, Vicens-Calvet E. Use of leuprolide acetate response patterns in the early diagnosis of pubertal disorders: comparison with the gonadotropin-releasing hormone test. J Clin Endocrinol Metab 1994;781:30-35. [Abstract] / [PDF]

10. Lawson ML, Cohen N. A single sample subcutaneous luteinizing hormone (LH)-releasing hormone (LHRH) stimulation test for monitoring LH suppression in children with central precocious puberty receiving LHRH agonists. J Clin Endocrinol Metab 1999;84:4536-4540. [Abstract] / [PDF]

11. Cook JS, Doty KL, Conn PM, Hansen JR. Assessment of depot leuprolide acetate dose-adequacy for central precocious puberty. J Clin Endocrinol Metab 1992;74:1206-1209. [Abstract] / [PDF]

12. Greulich WW, Pyle SI. Radiographic atlas of skeletal development of the hand and wrist. 2nd Ed. 1959 Stanford: Stanford University Press 1960;42:171. [PDF]
13. Neely EK, Hintz RL, Wilson DM, Lee PA, Gaultier T, Argente J, Stene M. Normal ranges for immunochemiluminometric gonadotropin assays. J Pediatr 1995;127:40-46. [Abstract] / [Full Text] / [PDF]

14. Resende EA, Lara BH, Reis JD, Ferreira BP, Pereira GA, Borges MF. Assessment of basal and gonadotropinreleasing hormone-stimulated gonadotropins by immunochemiluminometric and immunofluorometric assays in normal children. J Clin Endocrinol Metab 2007:92:1424-1429. [Abstract] / [Full Text] / [PDF]

15. Oerter KE, Uriarte MM, Rose SR, Barnes KM, Cutler GB Jr. Gonadotropin secretory dynamics during puberty in normal girls and boys. J Clin Endocrinol Metab 1990;71:1251-1258. [Abstract] / [PDF]

16. Brito VN, Batista MC, Borges MF, Latronico AC, Kohek MBF, Thirone ACP, Jorge BH, Arnhold IJP, Mendonca BB. Diagnostic value of fluorometric assays in the evaluation of precocious puberty. J Clin Endocrinol Metab 1999;84:3539-3544. [Abstract] / [Full Text] / [PDF]

17. Eckert KL, Wilson DM, Bachrach LK, Anhalt H, Habiby RL, Olney RC, Hintz RL, Neely EK. A single-sample, subcutaneous gonadotropin-releasing hormone test for central precocious puberty. Pediatrics 1996;97:517-519. [Abstract]

18. Jiang YJ, Liang L, Zhouliang ZC, Fu JF, Li Y, Hong F, Dong GP. Simplified gonadorelin stimulation test in diagnosis of precocious puberty. Zhejiang Da Xue Xue Bao Yi Xue Ban 2004;33:452-455. [Abstract]

19. Cavallo $A$, Zhou XH. LHRH test in the assessment of puberty in normal children. Horm Res 1994;41:10-15. [Abstract]

20. Brito VN, Latronico AC, Arnhold IJP, Mendonca BB. A single luteinizing hormone determination 2 hours after depot leuprolide is useful for therapy monitoring of gonadotropin-dependent precocious puberty in girls. J Clin Endocrinol Metab 2004;89:4338-4342. [Abstract] / [PDF]

21. Supornsilchai V, Hiranrat $P$, Wacharasindhu S, Srivuthana $S$, Aroonparkmongkol S. Basal luteinizing hormone/follicle stimulating hormone ratio in diagnosis of central precocious puberty. J Med Assoc Thai 2003;86:145-151. [Abstract]

22. Wacharasindhu S, Srivuthana S, Aroonparkmongkol $S$ Shotelersuk V. A cost-benefit of $\mathrm{GnRH}$ stimulation test in diagnosis of central precocious puberty (CPP). J Med Assoc Thai 2000;83:1105-1111. [Abstract] 